\title{
Comparison of hematological parameters between single and twin pregnancies in Dorper ewes during gestation, lambing, and postpartum
}

\author{
Bianca Paola Santarosa ${ }^{1,2^{*}}$ (i) Gabriela Nascimento Dantas ${ }^{2}$ (i) Danilo Otávio Laurenti Ferreira ${ }^{3}$ (D) \\ Henrique Barbosa Hooper $^{4}$ (D) Ana Carolina Rusca Correa Porto ${ }^{5}$ (D) \\ Silvia Maria França Carvalho Garcia ${ }^{5}$ (D) Soraya Regina Sacco Surian ${ }^{6}$ (D) \\ Paula Adriane Piccolo Pieruzzi ${ }^{4}$ (i) Andreza Amaral da Silva ${ }^{7}$ (i) Roberto Calderon Gonçalves $^{2}$ (i)
}

\author{
${ }^{1}$ Instituto de Ciências Agrárias (ICA), Universidade Federal dos Vales do Jequitinhonha e Mucuri (UFVJM), Campus Unaí, 38610-000, Unaí, \\ MG, Brasil. E-mail: biancasantarosavet@gmail.com. *Corresponding author. \\ ${ }^{2}$ Departamento de Clínica Veterinária, Faculdade de Medicina Veterinária e Zootecnia (FMVZ), Universidade Estadual Paulista (UNESP), \\ Botucatu, SP, Brasil. \\ ${ }^{3}$ Secretaria da Agricultura e Abastecimento do estado de São Paulo. Escritório de Defesa Agropecuária de Bauru, Bauru, SP, Brasil. \\ ${ }^{4}$ Anhanguera Educacional, Leme, SP, Brasil. \\ ${ }^{5}$ Universidade de Sorocaba (UNISO), Sorocaba, SP, Brasil. \\ ${ }^{6}$ Instituto Federal de Educação, Ciência e Tecnologia Catarinense, Concórdia, SC, Brasil. \\ ${ }^{7}$ Departamento de Medicina e Cirurgia Veterinária, Universidade Federal Rural do Rio de Janeiro (UFRRJ), Seropédica, RJ, Brasil.
}

\begin{abstract}
The hematopoietic system changes during the pregnancy to carry fetal development and maternal needs. This study compared the hematological parameters between ewes with single and twin pregnancies during gestation, delivery, and postpartum. The experiment was conducted on 60 healthy pregnant Dorper ewes that were divided into two experimental groups: Group 1 (G1), with single pregnancies ( $n=30)$, and Group 2 (G2), with twin pregnancies $(n=30)$. Blood samples were collected from all ewes at different times: immediately before fixedtime artificial insemination (AI); on day 30, 90, 120, 130, and 140 of pregnancy; immediately after delivery; and at 24h and 48h postpartum. Statistical analysis compared the two groups at different times $(P<0.05)$. Mild, normocytic, and hypochromic anemia was detected in all ewes from AI time and throughout pregnancy from both groups, but did not prove to be of clinical relevance. In the peripartum stage (from the 140 th day of pregnancy to 48 h postpartum), the ewes with twin pregnancies (G2) exhibited higher erythrogram values and neutrophil:lymphocyte ratio than did ewes with single pregnancies (G1). This indicated a greater hematopoietic adaptation in the body during the development of two fetuses. Except for the eosinophil numbers, all leukogram parameters were influenced by pregnancy in a similar way in both groups, and was characterized mainly by leukocytosis with neutrophilia during peripartum due to the high presence of endogenous cortisol at delivery. Thus, these findings showed that pregnancy was a stressful physiological event that increased the leukocyte count with a slight alteration in the erythrogram of Dorper ewes.
\end{abstract}

Key words: erythrogram, hematology, leukogram, single and twin pregnancies, sheep.

Comparação dos parâmetros hematológicos entre ovelhas Dorper de gestação simples e gemelar durante a prenhez, parto e pós-parto

RESUMO: O sistema hematopoiético sofre mudanças durante a gestação para atender o desenvolvimento fetal e as necessidades maternas. Este estudo comparou os parâmetros hematológicos entre ovelhas com gestação simples e gemelar durante a prenhez, parto e pós-parto. O estudo foi realizado em 60 ovelhas Dorper prenhes, saudáveis, divididas em dois grupos experimentais: Grupo 1 (G1) com gestação simples $(n=30)$; e Grupo 2 (G2) com gestação gemelar $(n=30)$. Amostras de sangue foram colhidos de todas as ovelhas em diferentes momentos: imediatamente antes da inseminação artificial em tempo fixo (IA); nos dias 30, 90, 120, 130 e 140 de gestação; imediatamente após o parto; $e$ às $24 h$ e 48 pós-parto. A análise estatística comparou os dois grupos nos diferentes momentos $(P<0,05)$. Anemia leve, normocítica e hipocrômica foi detectada desde a IA e ao longo da gestação, nas ovelhas de ambos os grupos, mas não houve relevância clínica. Na fase periparto (do $140^{\circ}$ dia de gestação às 48 h pós-parto), as ovelhas com gestação gemelar (G2) mostraram valores do eritrograma e proporção neutrófilos: linfócitos mais elevados do que as ovelhas com gestação simples (G1). Isso indicou maior adaptação hematopoiética da ovelha para o desenvolvimento de dois fetos. Com exceção do número de eosinófilos, todos os parâmetros do leucograma foram influenciados pela gestação de forma semelhante em ambos os grupos, e foi caracterizada principalmente por leucocitose com neutrofilia no periparto devido ao alto nível de cortisol endógeno no parto. Assim, os achados mostraram que a gestação foi um evento fisiológico estressante que aumentou a contagem de leucócitos com leve alteração no eritrograma de ovelhas Dorper.

Palavras-chave: eritrograma, gestação simples e gemelar, hematologia, leucograma, ovinos. 


\section{INTRODUCTION}

Important physiological changes during pregnancy determine the birth weight and neonatal viability of the fetus and lead to changes in the maternal hematopoietic system in different animal species including sheep. In addition to an ewe's nutritional requirements during pregnancy, high nutrient intake is also required during delivery and the peripartum and lactation periods for both the dam and the newborn lambs (PEREIRA et al., 2015). For the adaptation processes to the pregnancy period, the female is still affected by other factors such as nutrition, environment, breed, and climate (ANTUNOVIC et al., 2011; BEZERRA et al., 2017).

In addition to its low cost, hematological analysis provides reliable parameters of animal health, which, in association with other genetic, environmental, and management factors, can be very useful for disease diagnosis (OIKONOMIDIS et al., 2018).

The influence of pregnancy on the erythrogram has been studied in humans to elucidate the development of anemia. In women, physiological anemia, or anemia due to hemodilution, and hypervolemia in pregnant women has been noticed with a $40 \%$ increase in the volume of circulating blood (FORTAGNE \& SCHAFER, 1989; MBASSA \& POULSEN, 1991; MBASSA \& POULSEN, 1992; BARRY \& ANTHONY, 2008; MUSK et al., 2017). Research has been carried out in Brazil to study the influence of pregnancy, parturition, and peripartum on the blood count in cattle (OLIVEIRA et al., 2019), goats (VIANA et al., 2002; VIANA et al., 2003), and sheep (PEREIRA et al., 2015; BEZERRA et al., 2017). Pereira et al. (2015) reported blood count data of Santa Inês ewes on pasture from the 75 th day of pregnancy until the 75th day of lactation. Bezerra et al. (2017) described the hematological profile of the Santa Inês and Morada Nova sheep in all their reproductive stages, from non-pregnant to $60 \mathrm{~d}$ postpartum.

Other authors have evaluated the hematological profiles of sheep during pregnancy and lactation in different countries and breeds such as in the Merino (JELÍNEK et al., 1986; MUSK et al., 2017), Austrian Karakul (BAUMGARTNER \& PERNTHANER, 1994), Sakiz-Ivesi (YOKUS et al., 2004), Bighorn (BORJESSON et al., 2000), Tsigai (ANTUNOVIC et al., 2011), Awassi (BADAWI \& AL-HADITHY, 2014), Himalayan Gaddi (SHARMA et al., 2015), Barki (KANDIEL et al., 2016), and "fattailed" (ISLAM et al., 2018) sheep.
In Brazil, although there are studies related to the hematological parameters in sheep of the Lacaune (BRITO et al., 2006), Santa Inês (MCMANUS et al., 2009; LIMA et al., 2015; PEREIRA et al., 2015; BEZERRA et al., 2017), Morada Nova (DAVID et al., 2011; BEZERRA et al., 2013; BEZERRA et al., 2017), and Dorper breeds specifically (MADUREIRA et al., 2013; SANTAROSA, 2018; SANTAROSA et al., 2019), no study has been performed to monitor the health of Dorper ewes during pregnancy and the peripartum period via their hematological profiles, or to analyze this parameter in relation to the number of fetuses. Based on the importance of the Dorper breed for the sheep industry in Brazil, in this study we compared the hematological parameters between single and twin pregnancies in Dorper ewes during gestation, lambing, and postpartum.

\section{MATERIALS AND METHODS}

\section{Study area and climatic condition}

This study was carried out in a Monjolão sheep farm (Araí \& Zumbi) located in Pardinho city, São Paulo State, Brazil (2300'29'S; 48²2'50'W; $901 \mathrm{~m}$ ) from August, 2015 to January, 2016 The climate is classified according to the KöeppenGeiger classification as subtropical humid. The mean, minimum, and maximum air temperatures in the region were $21.14{ }^{\circ} \mathrm{C}, 16.16{ }^{\circ} \mathrm{C}$, and $27.56{ }^{\circ} \mathrm{C}$; the relative humidity was $76.53 \%$; the precipitation was $138.8 \mathrm{~mm}$; and the wind speed is $7.25 \mathrm{~m} / \mathrm{s}$.

\section{Experimental animals}

We selected 150 healthy non-pregnant Dorper ewes, 2 to 5 years old, with $49.79 \pm 10.54 \mathrm{~kg}$ body weight, and a body condition score of around 3-3.5 (RUSSEL, 1991). The animals were subjected to the estrus synchronization protocol described by SANTAROSA et al. (2019). Fixed-time artificial insemination (FTAI) was performed through frozen semen laparoscopy using semen from rams of the same breed. Pregnancy was confirmed $30 \mathrm{~d}$ after FTAI (TAVERNE et al., 1985; JONES \& REED, 2017) via transrectal examination using a portable ultrasound machine (My LabTM30 Vet Gold Esaote ${ }^{\circledR}$, Esaote Healthcare Brazil, São Paulo city, Brazil) equipped with a $5.0 \mathrm{MHz}$ linear transducer.

\section{Management of animals and experimental design}

The selected ewes were maintained in a semi-intensive system with access to a Vaquero grass pasture (cultivar Cynodon dactylon) during the day. 
The ewes were divided into two groups (G1 and G2) and housed in collective pens with rice-straw beds $\left(2 \mathrm{~m}^{2} /\right.$ animal $)$ by late afternoon, where they received corn silage and maintenance feed composed of corn, soybean, and wheat $(2: 1$ ratio; $1 \mathrm{~kg}$ of silage and $0.5 \mathrm{~kg}$ of feed/ewe) based on the maintenance nutritional requirements for pregnant sheep with single and twin pregnancies (NRC, 2007). Throughout the experiment, the animals had access to commercial mineral salt for sheep (Ovinofós ${ }^{\circledR}$ with Monensina, Tortuga Agrarian Zootechnical Company, MairinqueSP, Brazil) and water ad libitum in automatic troughs. Bromatological and mineral analysis of the total diet (feed, corn silage, and pasture) and body weight of the sheep at each time point (AI, G30, G90, G120, G130, G140, and L) were performed as described by Santarosa et al. (2019). The ewes were vaccinated 30 and $60 \mathrm{~d}$ before lambing against clostridiosis (Sintoxan-T Polivalente ${ }^{\circledR}$, Boehringer Ingelheim, Campinas-SP, Brazil), and deworming with Monepantel $(2,5 \mathrm{mg} / \mathrm{kg})$ orally (Monepantel $2,5 \%$, Zolvix ${ }^{\circledR}$, Novartis Health Animal, São PauloSP, Brazil) was carried out after delivery. At the end of the experimental period, the ewes remained on the farm during the lactation period with their lambs.

Based on the number of fetuses observed at the time of pregnancy diagnosis, the sheep were divided into two experimental groups: Group $1(\mathrm{G} 1)$ with an ultrasound confirmation of single pregnancy $(\mathrm{n}=30)$ and Group 2 (G2) with an ultrasound confirmation of twin pregnancies $(n=30)$. The nonpregnant animals were excluded from the study. Fetal viability was evaluated at 90, 120, 130, and $140 \mathrm{~d}$ of pregnancy using a convex transducer with a frequency of $3.5 \mathrm{MHz}$ (TAVERNE et al., 1985; JONES \& REED, 2017).

\section{Sampling of blood}

Nine experimental time points were defined for sample collection in this study: immediately before FTAI (AI); at 30d (G30), 90d (G90), 120d (G120), 130d (G130), and 140d (G140) of pregnancy; immediately after lambing (L); and at 24h (PP1) and $48 \mathrm{~h}$ (PP2) postpartum. The peripartum period refers to the few days before and after lambing, and for the purposes of this study it was considered from $140 \mathrm{~d}$ of pregnancy until $48 \mathrm{~h}$ postpartum.

All whole blood samples were collected in the morning from all ewes by venipuncture of the jugular vein using $30 \times 0.8 \mathrm{~mm}$ needles (BD Vacutainer $^{\circledR}$, BD Medical, Curitiba/PR, Brazil) into $5 \mathrm{~mL}$ vacuum tubes with ethylenediaminetetraacetic acid (EDTA) (BDVacutainer ${ }^{\circledR}$ ) as anticoagulant. The first six samples from all ewes were collected at the predetermined time points (AI, G30, G90, G120, G130 and G140), whereas the last three (L, PP1, and PP2) were collected according to the time of lambing of each ewe.

\section{Analysis of blood parameters}

Right after the collection, the samples were refrigerated immediately after collection and sent to the Clinical Pathology Service of the Veterinary Course at the University of Sorocaba (UNISO), Brazil where they were analyzed using an automatic veterinary hematological analyzer (Hemovet $2300^{\circledR}$; Brasmed, Brmd Produtos Cirúrgicos Eireli, Sumaré/ SP, Brazil) with commercial reagents (Diaton ${ }^{\circledR}$; Diago Soluções em Diagnóstico Ltda., Belo Horizonte/MG, Brazil). The red blood cell count (RBC), hemoglobin concentration (HGB), hematocrit (HCT), platelet concentration, and white blood cell count (WBC) for the samples were estimated. In addition, the mean corpuscular volume (MCV) and mean corpuscular hemoglobin concentration (MCHC) were also calculated using this equipment.

Blood smears for each sample were stained with a fast commercial Romanowsky dye (Panótico Rápido $^{\circledR}$; Laborclin Produtos para Laboratórios Ltda., Pinhais/PR, Brazil) and analyzed using a common optical microscope with a 1000x magnification (Nikon E200 ${ }^{\circledR}$ ) for assessing leukocyte differential, identifying polymorphonuclear granulocytes (segmented neutrophils, band neutrophils, basophils, and eosinophils), mononuclear agranulocytes (lymphocytes and monocytes). In this stage, the morphology (color, shape, and inclusions) of red blood cells and platelets was also evaluated. After differential leukocyte count, the neutrophil:lymphocyte (N/L) ratio was also determined (JAIN, 1993; BYERS \& KRAMER, 2010).

Two microhematocrit capillaries were filled up to $75 \%$ of their length with blood and centrifuged $\left(\mathrm{Celm}^{\circledR}\right.$; Celm Equipadora de Laboratórios Modernos, Barueri/SP, Brazil) for checking the HTC value and obtaining the total plasma protein (TPP) concentration. After $15 \mathrm{~min}$ of centrifugation, one capillary was used to determine the TPP using refractometry (Atago ${ }^{\circledR}$ T2 refractometer, NE Clinical, Atago Brasil Ltda., Ribeirão Preto-SP, Brazil), whereas the other was heated in a water bath (temperature $56^{\circ} \mathrm{C}$ to $57^{\circ} \mathrm{C}$ ) for $3 \mathrm{~min}$ and centrifuged again for $3 \mathrm{~min}$ to precipitate fibrinogen in the plasma. The TPP reading was also performed on the second capillary. The fibrinogen value expressed in $\mathrm{mg} / \mathrm{dL}$ was obtained from the difference in the TPP value of the first capillary and that of the second (JAIN, 1993). 


\section{Statistical analyses}

Statistical analyses was performed using the SigmaStat 3.5 software. The PROC X procedure was used to compare the RBC, WBC, segmented neutrophil, lymphocyte and platelet counts, and the HBG, HTC, TPP, MCV, and MCHC concentrations, and the $\mathrm{N} / \mathrm{L}$ ratio. A one-way repeated measures ANOVA was performed to compare the time points within each group followed by Tukey's multiple comparisons test to compare the means $(\mathrm{P}<0.05)$. The Student's t test was also performed to compare the two groups at each time $(\mathrm{P}<0.05)$. Nonparametric tests were used for band neutrophil, monocyte, and eosinophil counts and fibrinogen concentration due to abnormal data distribution. The Friedman test was used to compare all the time points within each group, followed by Tukey's test to compare the medians $(\mathrm{P}<0.05)$. At each time point, the Mann-Whitney test was also performed to compare these parameters of the two groups $(\mathrm{P}<0.05)$.

\section{RESULTS}

The mean erythrogram values in the G1 and G2 groups under different stages have been presented in table 1 . The RBC, HGB, HCT values during gestation in $\mathrm{G} 1$ ewes varied from $7.07 \pm 1.58$
(G120) to $8.23 \pm 1.77 \times 10^{6} / \mu \mathrm{L}$ (L), $7.56 \pm 1.34$ (G120) to $9.37 \pm 1.82 \mathrm{~g} / \mathrm{dL}(\mathrm{G} 30)$, and $29.4 \pm 7.4$ (PP2) to $35.3 \pm 5.2 \%$ (G90), respectively. In the $\mathrm{G} 2$ ewes the RBC, HGB, HCT values varied from 7.29 \pm 1.22 (G120) to $9.17 \pm 1.02 \times 10^{6} / \mu \mathrm{L}(\mathrm{L}), 7.77 \pm 1.42$ (G90) to $10.07 \pm 1.58 \mathrm{~g} / \mathrm{dL}(\mathrm{L})$, and $32.3 \pm 4.9$ (G130) to $37.3 \pm 4.9 \%(\mathrm{~L})$, respectively.

The mean erythrogram values in both G1 and G2 groups (Table 1) only differed $(\mathrm{P}<0.05)$ during the peripartum period for the $\mathrm{RBC}, \mathrm{HGB}$ and HTC concentrations; for these three parameters the means of the values obtained from the G2 ewes were higher than those from G1 ewes.

The MCV and MCHC (Table 2) concentrations showed variable behavior between time points $(\mathrm{P}<0.05)$ and the experimental groups. The $\mathrm{MCV}$ concentrations differed among the two groups at G120 $(\mathrm{P}=0.01), \mathrm{G} 140(\mathrm{P}=0.02)$, and $\mathrm{PP} 1(\mathrm{P}=0.002)$, whereas MCHC differed at AI $(\mathrm{P}<0.001), \mathrm{G} 30(\mathrm{P}<0.001), \mathrm{G} 140$ $(\mathrm{P}=0.044)$, $\mathrm{PP} 1(\mathrm{P}<0.001)$, and $\mathrm{PP} 2(\mathrm{P}<0.001)$.

There was no difference between the TPP, fibrinogen, and platelet (Table 3) concentrations between the two groups at any time point, but during pregnancy there was a difference during the time points within each group $(\mathrm{P}<0.0001)$.

As parturition is a physiological stress event, an increase in leukocytes was observed,

Table 1 - RBC, HGB and HCT of single (G1) and twin (G2) pregnancy Dorper ewes during prepartum, lambing and postpartum period.

\begin{tabular}{|c|c|c|c|c|c|c|c|c|c|}
\hline \multirow{2}{*}{ Times } & \multicolumn{2}{|c|}{$\mathrm{RBC}\left(\mathrm{x} 10^{6} / \mu \mathrm{L}\right)$} & \multirow{2}{*}{$\mathrm{P}$} & \multicolumn{2}{|c|}{ HGB $(g / d L)$} & \multirow{2}{*}{$\mathrm{P}$} & \multicolumn{2}{|c|}{ HTC (\%) } & \multirow{2}{*}{$\mathrm{P}$} \\
\hline & G1 & G2 & & G1 & $\mathrm{G} 2$ & & G1 & G2 & \\
\hline AI & $7.82 \pm 1.26^{\mathrm{a}}$ & $7.91 \pm 0.98^{\mathrm{b}}$ & 0.12 & $9.33 \pm 1.54^{\mathrm{a}}$ & $10.04 \pm 1.12^{\mathrm{a}}$ & 0.07 & $33.8 \pm 6.1^{\mathrm{a}}$ & $35.1 \pm 3.0^{\mathrm{ab}}$ & 0.34 \\
\hline G30 & $7.35 \pm 1.04^{\mathrm{a}}$ & $7.45 \pm 0.70^{\mathrm{b}}$ & 0.70 & $9.37 \pm 1.82^{\mathrm{a}}$ & $9.77 \pm 1.04^{\mathrm{ab}}$ & 0.37 & $33.2 \pm 6.8^{\mathrm{ab}}$ & $35.7 \pm 3.0^{\mathrm{ab}}$ & 0.11 \\
\hline G90 & $7.08 \pm 1.07^{\mathrm{ab}}$ & $7.32 \pm 0.98^{\mathrm{b}}$ & 0.46 & $7.56 \pm 1.34^{\mathrm{b}}$ & $7.77 \pm 1.42^{\mathrm{d}}$ & 0.58 & $35.3 \pm 5.2^{\mathrm{a}}$ & $35.5 \pm 6.5^{\mathrm{ab}}$ & 0.90 \\
\hline G120 & $7.07 \pm 1.58^{\mathrm{ab}}$ & $7.29 \pm 1.22^{\mathrm{b}}$ & 0.62 & $7.71 \pm 1.97^{\mathrm{b}}$ & $8.66 \pm 1.29^{\mathrm{bcd}}$ & 0.06 & $31.1 \pm 6.8^{\mathrm{ab}}$ & $32.8 \pm 4.6^{\mathrm{b}}$ & 0.31 \\
\hline G130 & $7.42 \pm 1.46^{\mathrm{a}}$ & $7.69 \pm 1.20^{\mathrm{b}}$ & 0.50 & $7.84 \pm 1.81^{\mathrm{b}}$ & $8.64 \pm 1.47^{\mathrm{cd}}$ & 0.09 & $31.2 \pm 7.0^{\mathrm{ab}}$ & $32.3 \pm 5.0^{\mathrm{b}}$ & 0.51 \\
\hline G140 & $7.63 \pm 1.60^{\mathrm{a}}$ & $8.62 \pm 0.81^{\mathrm{bc}}$ & 0.01 & $8.20 \pm 1.97^{\mathrm{b}}$ & $9.28 \pm 1.41^{\mathrm{abc}}$ & 0.03 & $33.1 \pm 7.6^{\mathrm{ab}}$ & $35.1 \pm 4.7^{\mathrm{ab}}$ & 0.27 \\
\hline $\mathrm{L}$ & $8.23 \pm 1.77^{\mathrm{ac}}$ & $9.17 \pm 1.02^{\mathrm{ac}}$ & 0.03 & $8.65 \pm 2.24^{\mathrm{ab}}$ & $10.0 \pm 1.58^{\mathrm{a}}$ & 0.01 & $33.2 \pm 8.7^{\mathrm{ab}}$ & $37.3 \pm 4.9^{\mathrm{a}}$ & 0.05 \\
\hline PP1 & $7.71 \pm 1.68^{\mathrm{a}}$ & $8.65 \pm 0.92^{\mathrm{bc}}$ & 0.02 & $8.12 \pm 2.21^{\mathrm{b}}$ & $9.57 \pm 1.63^{\mathrm{abc}}$ & 0.01 & $31.1 \pm 7.5^{\mathrm{ab}}$ & $35.8 \pm 6.0^{\mathrm{ab}}$ & 0.02 \\
\hline PP2 & $7.88 \pm 1.27^{\mathrm{a}}$ & $8.32 \pm 1.05^{\mathrm{bc}}$ & 0.20 & $8.07 \pm 1.87^{\mathrm{b}}$ & $9.24 \pm 1.76^{\mathrm{abc}}$ & 0.02 & $29.4 \pm 7.4^{\mathrm{b}}$ & $33.9 \pm 4.9^{\mathrm{ab}}$ & 0.01 \\
\hline $\mathrm{P}$ & 0.0058 & $<0.001$ & & $<0.001$ & $<0.001$ & & 0.001 & 0.002 & \\
\hline
\end{tabular}

Red blood cell count (RBC), hemoglobin (HBG), hematocrit (HTC). Data presented as mean \pm standard deviation. Artificial insemination time (AI), $30 \mathrm{~d}$ of pregnancy (G30), $90 \mathrm{~d}$ of pregnancy (G90), $120 \mathrm{~d}$ of pregnancy (G120), $130 \mathrm{~d}$ of pregnancy (G130), $140 \mathrm{~d}$ of pregnancy (G140), lambing (L), $24 \mathrm{~h}$ postpartum (PP1) and $48 \mathrm{~h}$ postpartum (PP2).

Means followed by the different lowercase letter in the column differed statistically by the Tukey test $(\mathrm{P}<0.05)$.

Reference interval: RBC 8-16 x 10\%/ LL; HBG 8-16g/dL; HTC 24-50\% (Jain, 1993; Meyer \& Harvey, 2004). 
Table 2 - MCV and MCHC of single (G1) and twin (G2) pregnancy Dorper ewes during prepartum, lambing and postpartum period.

\begin{tabular}{|c|c|c|c|c|c|c|}
\hline \multirow{2}{*}{ Times } & \multicolumn{2}{|c|}{ MCV (fL) } & \multirow{2}{*}{$\mathrm{P}$} & \multicolumn{2}{|c|}{$\mathrm{MCHC}(\mathrm{g} / \mathrm{dL})$} & \multirow{2}{*}{$\mathrm{P}$} \\
\hline & G1 & $\mathrm{G} 2$ & & G1 & G2 & \\
\hline AI & $43.3 \pm 5.14^{\mathrm{ab}}$ & $44.7 \pm 4.08^{\mathrm{ab}}$ & 0.28 & $28.0 \pm 4.27^{a}$ & $28.6 \pm 1.80^{\mathrm{a}}$ & $<0.001$ \\
\hline G30 & $45.3 \pm 7.66^{\mathrm{ab}}$ & $48.3 \pm 6.45^{\mathrm{a}}$ & 0.42 & $29.7 \pm 12.85^{\mathrm{ab}}$ & $27.4 \pm 2.05^{\mathrm{ab}}$ & $<0.001$ \\
\hline G90 & $51.4 \pm 13.42^{\mathrm{a}}$ & $49.1 \pm 9.94^{\mathrm{abc}}$ & 0.15 & $21.3 \pm 1.38^{\mathrm{bc}}$ & $22.0 \pm 2.30^{b c}$ & 0.12 \\
\hline G120 & $47.0 \pm 17.93^{\mathrm{abc}}$ & $46.3 \pm 10.2^{\mathrm{ab}}$ & 0.01 & $24.6 \pm 2.14^{\mathrm{abc}}$ & $26.5 \pm 2.86^{\mathrm{bc}}$ & 0.15 \\
\hline G130 & $43.4 \pm 12.41^{\mathrm{ab}}$ & $43.1 \pm 9.62^{\mathrm{ab}}$ & 0.23 & $25.2 \pm 2.29^{\mathrm{ab}}$ & $26.7 \pm 1.60^{\mathrm{abc}}$ & 0.09 \\
\hline G140 & $43.4 \pm 5.55^{\mathrm{ab}}$ & $40.7 \pm 3.35^{\mathrm{bc}}$ & 0.02 & $24.8 \pm 2.16^{\mathrm{abc}}$ & $26.4 \pm 1.40^{\mathrm{bc}}$ & 0.04 \\
\hline $\mathrm{L}$ & $40.0 \pm 4.27^{\mathrm{b}}$ & $40.7 \pm 3.57^{\mathrm{bc}}$ & 0.39 & $26.1 \pm 2.23^{\mathrm{abc}}$ & $27.0 \pm 2.88^{\mathrm{abc}}$ & 0.20 \\
\hline PP1 & $41.1 \pm 12.09^{b}$ & $41.3 \pm 5.17^{\mathrm{bc}}$ & 0.002 & $26.2 \pm 3.75^{\mathrm{abc}}$ & $26.7 \pm 1.18^{\mathrm{abc}}$ & $<0.001$ \\
\hline PP2 & $37.1 \pm 6.04^{\mathrm{bc}}$ & $40.8 \pm 4.86^{\mathrm{bc}}$ & 0.30 & $28.2 \pm 8.08^{\mathrm{abc}}$ & $27.2 \pm 2.65^{\mathrm{abc}}$ & $<0.001$ \\
\hline$P$ & $<0.001$ & $<0.001$ & & $<0.05$ & $<0.05$ & \\
\hline
\end{tabular}

Mean corpuscular volume (MCV), mean corpuscular hemoglobin concentration (MCHC). Data presented as mean \pm standard deviation. Artificial insemination time (AI), $30 \mathrm{~d}$ of pregnancy (G30), $90 \mathrm{~d}$ of pregnancy (G90), $120 \mathrm{~d}$ of pregnancy (G120), 130 d of pregnancy (G130), $140 \mathrm{~d}$ of pregnancy (G140), lambing (L), $24 \mathrm{~h}$ postpartum (PP1) and $48 \mathrm{~h}$ postpartum (PP2).

Means followed by the different lowercase letter in the column differed statistically by the Tukey test $(\mathrm{P}<0.05)$.

Reference interval: MCV 23-48fL; MCHC 31-38g/dL (Jain, 1993; Meyer \& Harvey, 2004).

especially in twin gestation. On comparing the parameters from the two groups (Table 4), it was found that ewes with twin pregnancies showed higher means than those with single pregnancies at $\mathrm{G} 90$ for $\mathrm{WBC}$ $(\mathrm{P}=0.026)$, segmented neutrophils $(\mathrm{P}=0.017)$, and lymphocytes $(\mathrm{P}=0.047)$. There were differences in the $\mathrm{N} / \mathrm{L}$ ratios (Table 4 ) over the time points analyzed in both groups $(\mathrm{P}<0.001)$ and between the groups in the prepartum period at $\mathrm{G} 30(\mathrm{P}=0.0068), \mathrm{G} 140(\mathrm{P}=0.0034)$, and postpartum $\mathrm{PP} 1(\mathrm{P}=0.003)$ and $\mathrm{PP} 2(\mathrm{P}=0.0448)$. The G2 ewes showed higher means of the N/L ratio compared to those in the G1 ewes from samples collected at these four time points. There was no evidence of toxic change in any leukocytes on smear exam.

The monocyte and eosinophil counts (Table 5) showed no difference between the groups studied. However, pregnancy changed the monocyte count over the analyzed time points for both groups of sheep $(\mathrm{P}<0.0001)$, whereas eosinophil count did not show significant change over time. The highest medians of monocytes were obtained at G30 in both groups.

\section{DISCUSSION}

The RBC and HGB values in both groups were below the reference range for the species (JAIN,
1993; MEYER \& HARVEY, 2004) during pregnancy, but were normal during the peripartum period. The mean values of HTC remained within the normal range throughout the observation period (JAIN, 1993; MEYER \& HARVEY, 2004). Slight relative anemia was observed in the sheep of both groups that could not be related to pregnancy as the values had oscillated over time and had presented a lower mean of RBC values than the normal range even at the time of FTAI. Initially, there was a decrease in the number of RBCs and the HGB concentration (G30), followed by an increase in these values at peripartum ( $\mathrm{G} 140$ to PP2). The HTC values, however, were normal and similar for both groups (JAIN, 1993; MEYER \& HARVEY, 2004), although with statistical differences between the time points, and did not bear clinical relevance in this study. This fact contradicted the findings of BRITO et al. (2006) who reported a decrease in HTC with the advancement of pregnancy.

In the peripartum period, the mean RBC count and HGB concentration increased and normalized in relation to the proposed reference interval for the species (JAIN, 1993; MEYER \& HARVEY, 2004) in both groups. This fact can be explained by the splenic contractions caused by the stress at the time of delivery that result in the consequent release of RBCs into the circulation. 
Table 3 - TPP concentration, fibrinogen concentration and platelets count of single (G1) and twin (G2) pregnancy Dorper ewes during prepartum, lambing and postpartum.

\begin{tabular}{|c|c|c|c|c|c|c|c|c|c|}
\hline \multirow{2}{*}{ Times } & \multicolumn{2}{|c|}{$\mathrm{TPP}(\mathrm{g} / \mathrm{dL})$} & \multirow{2}{*}{$\mathrm{P}$} & \multicolumn{2}{|c|}{ Fibrinogen(mg/dL) } & \multirow{2}{*}{$\mathrm{P}$} & \multicolumn{2}{|c|}{ 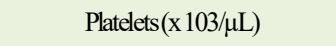 } & \multirow{2}{*}{$\mathrm{P}$} \\
\hline & G1 & $\mathrm{G} 2$ & & G1 & $\mathrm{G} 2$ & & G1 & $\mathrm{G} 2$ & \\
\hline $\mathrm{AI}$ & $7.74 \pm 0.40 \mathrm{abcd}$ & $7.84 \pm 0.3 a b c$ & 0.36 & $500[400-700] \mathrm{a}$ & $550[400-600] \mathrm{a}$ & 0.90 & $5.49 \pm 1.72 \mathrm{ab}$ & $5.40 \pm 1.73 \mathrm{ab}$ & 0.85 \\
\hline $\mathrm{G} 30$ & $8.16 \pm 0.47 \mathrm{a}$ & $8.17 \pm 0.38 \mathrm{a}$ & 0.88 & $200[200-400] \mathrm{abc}$ & $400[200-500] \mathrm{ab}$ & 0.24 & $6.14 \pm 1.78 \mathrm{a}$ & $5.34 \pm 1.76 a b$ & 0.11 \\
\hline G90 & $7.93 \pm 0.51 \mathrm{abc}$ & $7.87 \pm 0.4 a b c$ & 0.64 & $200[100-400] \mathrm{cd}$ & $200[100-400] \mathrm{bc}$ & 0.45 & $4.22 \pm 1.58 \mathrm{~d}$ & $4.21 \pm 1.62 b$ & 0.97 \\
\hline G120 & $7.66 \pm 0.69 \mathrm{~cd}$ & $7.67 \pm 0.32 b c$ & 0.94 & $100[100-225] \mathrm{d}$ & $100[100-200] \mathrm{c}$ & 0.55 & $5.06 \pm 1.37 \mathrm{bc}$ & $4.73 \pm 1.03 \mathrm{ab}$ & 0.35 \\
\hline G130 & $7.38 \pm 0.67 d$ & $7.52 \pm 0.39 c$ & 0.39 & $300[200-400] \mathrm{abc}$ & $250[200-400] \mathrm{bc}$ & 0.22 & $5.53 \pm 1.27 \mathrm{ab}$ & $5.12 \pm 1.04 a b$ & 0.22 \\
\hline G140 & $7.93 \pm 0.77 \mathrm{abc}$ & $8.19 \pm 0.39 \mathrm{a}$ & 0.16 & $200[200-300] \mathrm{bcd}$ & $300[200-400] \mathrm{bc}$ & 0.18 & $5.54 \pm 1.26 \mathrm{ab}$ & $5.29 \pm 1.08 \mathrm{ab}$ & 0.46 \\
\hline $\mathrm{L}$ & $8.13 \pm 0.78 \mathrm{ab}$ & $8.04 \pm 0.44 a b$ & 0.56 & $200[100-600] \mathrm{bcd}$ & $250[200-400] \mathrm{bc}$ & 0.69 & $6.00 \pm 1.45 \mathrm{ab}$ & $5.90 \pm 1.46 \mathrm{a}$ & 0.80 \\
\hline PP1 & $7.74 \pm 0.77 \mathrm{abc}$ & $7.95 \pm 0.67 \mathrm{ab}$ & 0.34 & $400[200-425] \mathrm{ab}$ & $350[200-400] \mathrm{ab}$ & 0.43 & $6.32 \pm 1.28 \mathrm{a}$ & $5.69 \pm 1.56 \mathrm{a}$ & 0.11 \\
\hline PP2 & $7.71 \pm 0.88 \mathrm{bcd}$ & $7.75 \pm 0.46 b c$ & 0.85 & $400[200-625] \mathrm{ab}$ & $400[200-500] \mathrm{ab}$ & 0.88 & $6.14 \pm 1.13 a$ & $5.51 \pm 1.27 \mathrm{a}$ & 0.06 \\
\hline $\mathrm{P}$ & $<0.001$ & $<0.001$ & & $<0.001$ & $<0.001$ & & $<0.001$ & 0.002 & \\
\hline
\end{tabular}

Total Plasma Protein (TPP). Data presented as mean \pm standard deviation, and median [first - third percentilis].

Artificial insemination time (AI), $30 \mathrm{~d}$ of pregnancy (G30), $90 \mathrm{~d}$ of pregnancy (G90), $120 \mathrm{~d}$ of pregnancy (G120), 130 d of pregnancy (G130), $140 \mathrm{~d}$ of pregnancy (G140), lambing (L), $24 \mathrm{~h}$ postpartum (PP1) and $48 \mathrm{~h}$ postpartum (PP2).

Mean followed by different lowercase letter in the column differed statistically by the Tukey test $(\mathrm{P}<0.05)$. Median followed by different lowercase letter in the column differed statistically by the Tukey test $(\mathrm{P}<0.05)$

Reference interval: TPP 6.0-7.5g/dL; fibrinogen 100-500mg/dL; platelets 300-600 x 103/ $\mu \mathrm{L}$ (Meyer \& Harvey, 2004; Kaneko et al., 2008).

These contractions provide a transient impression of a large mass of erythrocytes in the bloodstream but have no clinical importance because the RBC count returns to normal within a short time (THRALL et al., 2015). In this study, however, the RBC count at PP2 still remained high and statistically similar to that at lambing time, which can be associated with fluid losses that occur during parturition and result in relative erythrocytosis.

Twin pregnancy ewes had higher means of HBG and HTC compared to those in single pregnancy ewes in the peripartum period due to greater demand for oxygen supply for the final growth of lambs and for lambing. In addition, it can be explained by the pronounced splenic contraction required for fetal expulsion in twin lambs (JAIN, 1993). This finding did not corroborate that by MUSK et. al. (2017) who described higher HGB concentrations in sheep with single fetuses at 111 to $125 \mathrm{~d}$ of gestation.

MUSK et al. (2017) did not find anemia in 25 pregnant Merino ewes in Australia. There are several reasons that can commonly cause anemia in sheep, such as parasitism by Haemonchus contortus, trauma, clostridiosis, and undernourishment (MUSK et al., 2017). As the ewes in the present study were healthy, vaccinated, and well-fed, the parameters such as RBC, HGB, and HCT were normal throughout the experimental period. The same parameters were higher during peripartum than at prepartum, which might be justified by the loss of fluids during delivery and less voluntary water intake due to reduced ruminal size caused by uterine expansion during pregnancy (BEZERRA et al., 2017).

On comparing the mean values to the reference range of sheep's $\mathrm{MCV}$, higher values were noted at G90 for both groups indicating macrocytosis (JAIN, 1993), whereas the other values remained within the normal ranges for this species. All the means for $\mathrm{MCHC}$ were below the normal range (JAIN, 1993) indicating hypochromia and were as described by other authors (BEZERRA et al., 2013; MADUREIRA et al., 2013; PEREIRA et al., 2015; BEZERRA et al., 2017). SALVIANO et al. (2013), who determined normal hematological values in healthy non-pregnant Santa Inês ewes in Piauí State, Brazil, also reported lower levels of MCHC compared to those in the literature but attributed this finding to adaptations to the semiarid climate.

Ciência Rural, v.52, n.1, 2022. 
Table 4 - WBC, segmented neutrophils, lymphocytes and the neutrophil/lymphocyte ratio of single (G1) and twin (G2) pregnant Dorper ewes during prepartum, lambing and postpartum.

\begin{tabular}{|c|c|c|c|c|c|c|c|c|c|c|c|c|}
\hline \multirow{2}{*}{ Times } & \multicolumn{2}{|c|}{$\mathrm{WBC} \times 10^{3} / \mu \mathrm{L}$} & \multirow{2}{*}{$\mathrm{P}$} & \multicolumn{2}{|c|}{ Seg. Neutrophils $\mu \mathrm{L}$} & \multirow{2}{*}{$\mathrm{P}$} & \multicolumn{2}{|c|}{ Lymphocytes/ $\mu \mathrm{L}$} & \multirow{2}{*}{$\mathrm{P}$} & \multicolumn{2}{|c|}{ Neutrophils/Lymphocytes } & \multirow{2}{*}{$\mathrm{P}$} \\
\hline & G1 & $\mathrm{G} 2$ & & G1 & $\mathrm{G} 2$ & & G1 & $\mathrm{G} 2$ & & Gl & G2 & \\
\hline AI & $15.0 \pm 4.38^{\mathrm{db}}$ & $15.4 \pm 4.63^{\mathrm{d}}$ & 0.78 & $8.23 \pm 3.18^{b}$ & $7.91 \pm 2.92^{\mathrm{dd}}$ & 0.71 & $6.08 \pm 2.50^{\mathrm{a}}$ & $6.38 \pm 3.37^{a}$ & 0.71 & $1.62 \pm 1.05^{\mathrm{b}}$ & $1.62 \pm 1.19^{b}$ & 0.59 \\
\hline $\mathrm{G} 30$ & $13.1 \pm 4.77^{x}$ & $12.7 \pm 4.29^{\mathrm{kc}}$ & 0.75 & $6.89 \pm 3.35^{b x}$ & $6.16 \pm 2.48^{\mathrm{d}}$ & 039 & $5.29 \pm 2.44^{a b}$ & $5.48 \pm 2.53^{\mathrm{b}}$ & 0.78 & $1.54 \pm 0.91^{b}$ & $1.57 \pm 1.59^{b}$ & 0.006 \\
\hline G90 & $6.81 \pm 2.37^{\mathrm{d}}$ & $9.01 \pm 4.39^{\mathrm{dd}}$ & 0.02 & $3.01 \pm 1.30^{\mathrm{d}}$ & $4.08 \pm 1.79^{e}$ & 0.01 & $3.31 \pm 1.53^{\mathrm{c}}$ & $4.43 \pm 2.39^{\mathrm{k}}$ & 0.04 & $1.05 \pm 0.61^{\mathrm{bd}}$ & $1.08 \pm 0.58^{b}$ & 0.84 \\
\hline $\mathrm{G} 120$ & $10.0 \pm 3.99^{c}$ & $9.16 \pm 3.63^{\mathrm{dd}}$ & 0.43 & $5.28 \pm 2.64^{\mathrm{dd}}$ & $4.53 \pm 2.66^{\mathrm{e}}$ & 032 & $4.18 \pm 2.09^{b x}$ & $3.95 \pm 1.60^{x x}$ & 0.66 & $1.53 \pm 0.96^{b}$ & $1.25 \pm 0.71^{\mathrm{b}}$ & 0.15 \\
\hline G130 & $8.92 \pm 3.86^{\mathrm{dd}}$ & $9.09 \pm 3.38^{\mathrm{dd}}$ & 0.86 & $4.89 \pm 3.14^{\mathrm{dd}}$ & $4.96 \pm 2.67^{\circ}$ & 0.93 & $3.60 \pm 1.21^{\mathrm{c}}$ & $3.63 \pm 1.20^{x}$ & 091 & $1.40 \pm 0.77^{b}$ & $1.43 \pm 0.86^{b}$ & 0.64 \\
\hline G140 & $9.01 \pm 3.18^{\text {ed }}$ & $10.4 \pm 4.24^{\mathrm{dd}}$ & 0.17 & $4.75 \pm 1.69^{\mathrm{dd}}$ & $6.16 \pm 3.71^{\mathrm{d}}$ & 0.07 & $3.71 \pm 1.95^{\mathrm{c}}$ & $3.84 \pm 1.73^{\mathrm{bx}}$ & 0.81 & $1.59 \pm 0.93^{\mathrm{b}}$ & $1.95 \pm 1.70^{b}$ & 0.003 \\
\hline $\mathrm{L}$ & $16.9 \pm 5.61^{\mathrm{a}}$ & $17.3 \pm 5.30^{\mathrm{a}}$ & 0.77 & $12.3 \pm 5.16^{\mathrm{a}}$ & $13.1 \pm 5.34^{\mathrm{a}}$ & 0.59 & $3.84 \pm 1.80^{\mathrm{bx}}$ & $3.33 \pm 1.87^{\circ}$ & 032 & $4.33 \pm 5.13^{\mathrm{a}}$ & $5.61 \pm 4.34^{\mathrm{a}}$ & 0.43 \\
\hline PP1 & $16.6 \pm 3.83^{\mathrm{a}}$ & $16.8 \pm 4.76^{\mathrm{a}}$ & 0.56 & $11.2 \pm 3.29^{\mathrm{a}}$ & $11.5 \pm 4.29^{\text {b }}$ & 0.74 & $3.65 \pm 1.75^{\mathrm{c}}$ & $3.94 \pm 2.42^{\mathrm{bx}}$ & 0.62 & $3.84 \pm 2.35^{\mathrm{a}}$ & $4.80 \pm 4.99^{\mathrm{a}}$ & 0.003 \\
\hline PP2 & $16.3 \pm 3.22^{\mathrm{a}}$ & $15.7 \pm 3.88^{\mathrm{db}}$ & 0.51 & $10.7 \pm 3.31^{\mathrm{a}}$ & $10.1 \pm 3.16^{\mathrm{bc}}$ & 0.51 & $4.53 \pm 1.64^{\mathrm{bx}}$ & $4.67 \pm 2.15^{\mathrm{abc}}$ & 0.79 & $2.77 \pm 1.43^{\mathrm{bx}}$ & $2.87 \pm 2.15^{b}$ & 0.04 \\
\hline $\mathrm{P}$ & $\triangleleft 0.001$ & $\triangleleft 0.001$ & & $<0.001$ & $\triangleleft 0.001$ & & $<0.001$ & $\triangleleft 0.001$ & & $\triangleleft 0.001$ & $\triangleleft 0.001$ & \\
\hline
\end{tabular}

White blood cell count (WBC). Data presented as mean \pm standard deviation.

Artificial insemination time (AI), $30 \mathrm{~d}$ of pregnancy (G30), $90 \mathrm{~d}$ of pregnancy (G90), $120 \mathrm{~d}$ of pregnancy (G120), 130 d of pregnancy (G130), $140 \mathrm{~d}$ of pregnancy (G140), lambing (L), $24 \mathrm{~h}$ postpartum (PP1) and $48 \mathrm{~h}$ postpartum (PP2).

Mean followed by different lowercase letter in the column differed statistically by the Tukey test $(\mathrm{P}<0.05)$.

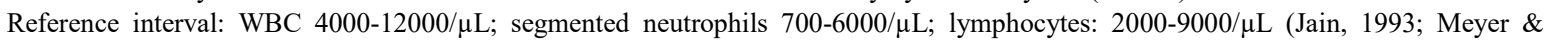
Harvey, 2004).

The occurrence of hypochromic normocytic anemia in samples collected at FTAI and during pregnancy, except for those collected at G90 that showed macrocytosis, from both groups can be related to the health of these ewes in certain conditions and the greater resistance of the Dorper breed to helminths (STARLING et al., 2019). Thus, iron deficiency in these sheep could be related to asymptomatic worms, as parasitism by $H$. contortus can cause hypochromia (BIRGEL et al., 2014). Other factors that could lead to iron deficiency such as ulcers, tumors, and deficiency of copper and vitamin B (MOHAMMED et al., 2014; THRALL et al., 2015) were also excluded as the animals received a mineral mixture ad libitum and core of vitamins with the concentrate.

Other indicators that exclude worms in these sheep were the absence of eosinophilia and hypoproteinemia at the time points analyzed (Tables 3 and 5) as these findings suggest the absence of parasitism (MOHAMMED et al., 2014).

The TPP (Table 3 ) values at all time points, except at G130, in both experimental groups were above the normal values for the species (KANEKO et al., 2008). The mean platelet count (Table 3 ) and the median fibrinogen concentration (Table 3 ) remained within the reference range for sheep (MEYER \& HARVEY, 2004; KANEKO et al., 2008) at all time points and in both groups.

The TPP means were above the standard value, which could be the result of sound nutritional management with adequate crude protein in the diet, similar to those described by SANTAROSA et al. (2019) who found higher levels of serum albumin in single and twin pregnancies ewes. The TPP values were similar to those described by MUSK et al. (2017) who compared hematological parameters from seven samples obtained from ewes with single and twin pregnancies and found them to be higher than those in non-pregnant, non-lactating sheep. Similar to the findings in this study, other authors have also reported higher levels of TPP in the peripartum period (BEZERRA et al., 2017), which can be justified by the increase in serum globulin due to colostrum production (SANTAROSA et al., 2019) in addition to the fluid losses (hemoconcentration) that occur during delivery.

Regarding fibrinogen and platelets (Table 3), although with statistical difference over time it was not possible to correlate the medians 
Table 5 - Band neutrophils, monocytes and eosinophils count of single (G1) and twin (G2) pregnant Dorper ewes during prepartum, lambing and postpartum.

\begin{tabular}{|c|c|c|c|c|c|c|c|c|c|}
\hline \multirow{2}{*}{ Times } & \multicolumn{2}{|c|}{ Band neutrophils $/ \mu \mathrm{L}$} & \multirow{2}{*}{$P$} & \multicolumn{2}{|c|}{ Monocytes $/ \mu \mathrm{L}$} & \multirow{2}{*}{$\mathrm{P}$} & \multicolumn{2}{|c|}{ Eosinophils $/ \mu \mathrm{L}$} & \multirow[t]{2}{*}{$\mathrm{P}$} \\
\hline & G1 & G2 & & G1 & G2 & & G1 & G2 & \\
\hline $\mathrm{AI}$ & $0.0[0.0-252]^{\mathrm{db}}$ & $118[0.0-207]^{\mathrm{dc}}$ & 0.81 & $0.0[0.0-163]^{\mathrm{b}}$ & $112[0.0-253]^{d b}$ & 0.35 & $393[188-688]$ & $528[270-906]$ & 0.33 \\
\hline $\mathrm{G} 30$ & $0.0[0.0-208]^{\mathrm{ab}}$ & $130[70.0-394]^{\mathrm{abc}}$ & 0.07 & $149[49.5-309]^{\mathrm{a}}$ & $146[0.0-210]^{a}$ & 0.67 & $225[117-430]$ & $305[136.3-664]$ & 0.36 \\
\hline G90 & $29.0[0.0-112]^{\mathrm{b}}$ & $0.0[0.0-124]^{c}$ & 0.85 & $0.0[0.0-45.0]^{\mathrm{b}}$ & $0.0[0.0-124] \mathrm{ab}$ & 0.40 & $336[113-605]$ & $226[99.0-420]$ & 0.53 \\
\hline G120 & $0.0[0.0-122]^{\mathrm{db}}$ & $0.0[0.0-232]^{\mathrm{abc}}$ & 0.73 & $0.0[0.0-82.5]^{\mathrm{ab}}$ & $0.0[0.0-0.0]^{\mathrm{db}}$ & 0.20 & $335[60.0-438]$ & $375[156-685]$ & 0.23 \\
\hline G130 & $0.0[0.0-123]^{\mathrm{b}}$ & $0.0[0.0-120]^{b c}$ & 0.71 & $0.0[0.0-0.0]^{\mathrm{b}}$ & $0.0[0.0-69]^{\mathrm{bb}}$ & 0.22 & $280[87.5-460]$ & $349[174-525]$ & 0.52 \\
\hline G140 & $36.0[0.0-130]^{\mathrm{ab}}$ & $69.5[0.0-128]^{b c}$ & 0.69 & $0.0[0.0-0.0]^{\mathrm{b}}$ & $0.0[0.0-0.0]^{\mathrm{b}}$ & 0.30 & $308[222-648]$ & $375[201-441]$ & 0.48 \\
\hline $\mathrm{L}$ & $162[0.0-357]^{\mathrm{ab}}$ & $311[0.0-496]^{\mathrm{db}}$ & 0.18 & $0.0[0.0-193]^{\mathrm{ab}}$ & $0.0[0.0-330]^{\mathrm{ab}}$ & 0.40 & $87.0[0.0-669]$ & $100[0.0-412]$ & 0.88 \\
\hline PP1 & $340[0.0-508]^{\mathrm{a}}$ & $433[193.0-630]^{\mathrm{a}}$ & 0.21 & $0.0[0.0-264]^{\mathrm{ab}}$ & $0.0[0.0-390]^{\mathrm{ab}}$ & 0.30 & $471[0.0-1245]$ & $294[0.0-900]$ & 0.42 \\
\hline PP2 & $171[0.0-582]^{\mathrm{ab}}$ & $285[0.0-504]^{\mathrm{adc}}$ & 0.59 & $0.0[0.0-0.0]^{\mathrm{b}}$ & $0.0[0.0-0.0]^{\mathrm{ab}}$ & 0.95 & $342[0.0-954]$ & $253[0.0-519]$ & 0.27 \\
\hline $\mathrm{P}$ & 0.012 & $<0.001$ & & $<0.001$ & $<0.001$ & & 0.27 & 0.17 & \\
\hline
\end{tabular}

Data presented as median [first - third percentilis].

Artificial insemination time (AI), $30 \mathrm{~d}$ of pregnancy (G30), $90 \mathrm{~d}$ of pregnancy (G90), $120 \mathrm{~d}$ of pregnancy (G120), $130 \mathrm{~d}$ of pregnancy (G130), $140 \mathrm{~d}$ of pregnancy (G140), lambing (L), $24 \mathrm{~h}$ postpartum (PP1) and $48 \mathrm{~h}$ postpartum (PP2).

Median followed by different lowercase letter in the column differed statistically by the Tukey test $(\mathrm{P}<0.05)$.

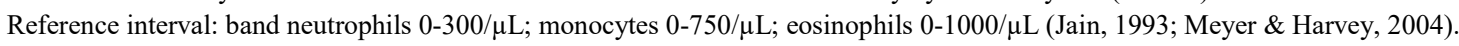

and means with the gestational period, because the animals were clinically healthy and the values had remained normal. However, comparing the time of lambing with PP1 and PP2 postpartum, it was noted that there was an increase in fibrinogen values in both groups. This occurrence can be explained by the fact that fibrinogen is a acute-phase protein, which result in an increase in inflammatory and other processes that involve tissue destruction similar to those that occur during a normal delivery (JAIN, 1993; CHALHOUB et al., 2000). However, these data are insufficient to extrapolate the reference range for the species, as this is a physiological event.

Here we analyzed the platelet count and fibrinogen concentration together with the hematological values during pregnancy. Similar to the present study, DAVID et al. (2011) did not observe any difference in fibrinogen levels in the last 45d before delivery in Morada Nova ewes. SHARMA et al. (2015) reported a decrease in platelets during the postpartum period in Gaddi sheep, which differed from the increase found in the present study. MOHAMMED et al. (2014) found no difference among the fibrinogen levels in sheep at the end of gestation, in non-pregnant or lactating sheep, and in lambs.
In the leukogram, leukocytosis with neutrophilia (Table 4) was observed in samples collected at the initial time points (AI and G30) and later at lambing (L) and postpartum (PP1 and PP2) in both groups (JAIN, 1993; MEYER \& HARVEY, 2004). The median values of the bands (Table 5), in turn, were above the normal range for the species only at PP1 in both groups, but still as marginal values (JAIN, 1993; MEYER \& HARVEY, 2004). The monocyte and eosinophil numbers (Table 5) remained within the normal range for sheep (JAIN, 1993; MEYER \& HARVEY, 2004) in both groups and at all time points.

The WBCs for both experimental groups showed the same behavior, and the leukocytosis with neutrophilia found at the beginning of the experimental period and in the peripartum period can be explained by the elevated cortisol levels as shown by SANTAROSA (2018). At the time of the FTAI and at G30, the animals were in the adaptation process of handling and restraint. Hence, the secretion of stress hormones may have resulted in the release of mature neutrophils into the circulation (MEYER \& HARVEY, 2004). Even more pronounced leukocytosis with neutrophilia was detected during delivery and postpartum, including a slight left shift 
(Table 5) due to the increase in cortisol, which triggers delivery. The adrenal glands of lambs secrete corticosteroids, which cause neutrophil endothelial demargination resulting in a temporary increase in neutrophils (BYERS \& KRAMER, 2010; FONTEQUE et al., 2013).

Lymphocytes showed a tendency to decrease moderately with the progress of pregnancy and the proximity of delivery. In both groups, it was noted that there was a decrease in the number of lymphocytes at G90 and an increase at G120, which can be explained by the vaccination that occurred during this period resulting in the production of new lymphocytes that produce new antibodies (MEYER \& HARVEY, 2004).

Therefore, it was noted that there was an inversion in the N/L ratio (Table 4 ) in relation to ruminant physiology (JAIN 1993, MEYER \& HARVEY 2004), which agreed with the findings of BEZERRA et al. (2017) in sheep and those of FONTEQUE et al. (2013) in goats. In addition, in G2 ewes there were higher N/L ratios that may probably be explained by the greater effect of the endogenous cortisol secreted by the two lambs at G140 to signal delivery, and then, at PP1 and PP2, the leukogram stress profile was more accentuated compared to that in G1 ewes. In the peripartum period, several factors contribute to this condition such as growth, milk production, and uterine involution (BEZERRA et al., 2017), which we found to be more accentuated in ewes with twin pregnancies.

The changes that occurred at the time close to lambing, related to physiological stress, determined a marked increase in the number of WBCs due to neutrophilia and the presence of band neutrophils, which was characterized with a slight left shift in both groups. These observations agree with the possible action of the high concentration of cortisol on the bone marrow and on the neutrophils present in the bloodstream (FONTEQUE et al., 2013).

The medians of monocytes showed a significant change during the gestation period, with a significant increase on the day of lambing and at PP1, with a decrease at PP2 in both groups. The medians of eosinophils showed no difference over time. At the time of delivery, however, the medians of eosinophils decreased notably, which may be explained by the stress triggered by endogenous cortisol release at parturition (FONTEQUE et al., 2013).

\section{CONCLUSIONS}

Pregnancy was a stressful physiological event for the Dorper ewes and it promoted an increase in the leukocyte count, even if no clinical relevant alteration in the erythrogram. At lambing, the main finding was the increase of neutrophils, that reduces as time goes by on post-partum until 48 hours. Hence, the leukogram parameters were influenced by pregnancy in both groups, which was elucidated mainly by leukocytosis with neutrophilia in the peripartum period and was related to the increase of endogenous cortisol.

\section{ACKNOWLEDGMENTS}

The authors thank the School of Veterinary Medicine and Animal Science of Universidade Estadual Paulista (FMVZ/UNESP); the Clinic Laboratory of Veterinary Medicine course of Universidade de Sorocaba (UNISO), for providing the infrastructure and equipment that were used to conduct the experiment; the Fundação de Amparo à Pesquisa do Estado de São Paulo (FAPESP) for the regular grant for our research project [Process 2015/08714-8], and the Coordenação de Aperfeiçoamento de Pessoal de Nível Superior (CAPES) for the PhD scholarship granted to the first author (BPS). They are also grateful to the management and employees of the Monjolão sheep farm (Araí \& Zumbi) located in Pardinho, São Paulo State, for allowing the use of their livestock and for their assistance in sample collection.

\section{BIOETHICS AND BIOSSECURITY COMMITTEE APPROVAL}

This research was approved by the Ethics Committee on the Use of Animals (CEUA) of the School of Veterinary Medicine and Animal Science (FMVZ), UNESP, Botucatu Campus (Protocol No. 189/2014).

\section{DECLARATION OF CONFLICT OF INTEREST}

The authors declare no conflicts of interest. The founding sponsors had no role in the design of the study; in the collection, analyses or interpretation of data; in the writing of the manuscript; or in the decision to publish the results.

\section{AUTHORS' CONTRIBUTIONS}

All authors contributed equally for the conception and writing of the manuscript. All authors critically revised the manuscript and approved of the final version.

\section{REFERENCES}

ANTUNOVIC, Z. et al. Blood metabolic profile and some of hormones concentration in ewes during different physiological status. Bulgarian Journal of Agricultural Science, v.17, n.5, p.687-695, 2011. Available from: <https://www.agrojournal. org/17/05-16-11.pdf>. Accessed: Apr. 12, 2020.

BADAWI, N.M.; AL-HADITHY, H.A. The hematological Parameters in Clinically Healthy Iraqi Awassi Sheep. World's 
Veterinary Journal, v.41, n.1, p.1-5, 2014. Available from: $<$ http://wvj.science-line.com/attachments/article/21/World's $\% 20$ Vet.\%20J.\%204(1)\%2001-05,\%202014.pdf>. Accessed: Apr. 12, 2020. doi: $10.5455 /$ wvj. 20140237 .

BARRY, J.S.; ANTHONY, R.V. The pregnant sheep as a model for human pregnancy. Theriogenology, v.69, p.55-67, 2008. Available from: <.https://www.ncbi.nlm.nih.gov/pmc/articles/PMC2262949/ pdf/nihms35971.pdf. $>$. Accessed: Apr. 12, 2020. doi: 10.1016/j. theriogenology.2007.09.021.

BAUMGARTNER, W.; PERNTHANER, A. Influence of age, season and pregnancy upon blood parameters in Austrian Karakul sheep. Small Ruminant Research, v.13, n.2, p.147-151, 1994. Available from: <https://doi.org/10.1016/0921-4488(94)900906>. Accessed: Apr. 12, 2020. doi: 10.1016/0921-4488(94)90090-6.

BEZERRA, L.R. et al. Comparative hematological analysis of Morada Nova and Santa Inês ewes in all reproductive stages. Pesquisa Veterinária Brasileira, v.37, n.4, p.408414, 2017. Available from: <https://doi.org/10.1590/s0100736x2017000400017>. Accessed: Apr. 12, 2020. doi: 10.1590/ s0100-736x2017000400017.

BEZERRA, L.R. et al. Influence of concentrate supplementation and the animal category in the hemogram of Morada Nova sheep. Arquivo Brasileiro de Medicina Veterinária e Zootecnia, v.65, n.6, p.1738-1744, 2013. Available from: <https://doi.org/10.1590/ S0102-09352013000600022>. Accessed: Apr. 12, 2020. doi: 10.1590/S0102-09352013000600022.

BIRGEL, D.B. et al. Evaluation of the erythrocyte pattern and the repercussions of anemic status in white blood cells of goats with gastrointestinal helminthiasis. Pesquisa Veterinária Brasileira, v.34, n.3, p.199-204, 2014. Available from: <http://dx.doi. org/10.1590/S0100-736X2014000300001>. Accessed: Apr. 12, 2020. doi: 10.1590/S0100-736X2014000300001.

BORJESSON, D.L. et al. Biochemical and hematologic reference intervals for free-ranging desert Bighorn sheep. Journal of Wildlife Diseases, v.36, n.2, p.294-300, 2000. Available from: $<$ https://doi.org/10.7589/0090-3558-36.2.294>. Accessed: Apr. 12, 2020. doi: 10.7589/0090-3558-36.2.294.

BRITO, M.A. et al. Blood and milk composition in dairy ewes from southern Brazil: variations during pregnancy and lactation. Ciência Rural, v.36, n.3, p.942-948, 2006. Available from: <http:// dx.doi.org/10.1590/S0103-84782006000300033>. Accessed: Apr. 12, 2020. doi: 10.1590/S0103-84782006000300033.

BYERS, S.R.; KRAMER, J.W. Normal hematology of sheep and goats. In: Weiss D.J., \& Wardrop K.J. (Eds) Schalm's veterinary hematology. $6^{\text {a }}$ ed. Ames, IA, Blackwell Publishing Ltd. p. 836842, 2010.

CHALHOUB, M. et al. Profile of blood components at immediate puerperium of ewes submitted to cesarean section and of those which had normal parturition. Arquivo Brasileiro de Medicina Veterinária e Zootecnia, v.52, n.5, p.440-443, 2000. Available from: <https://doi.org/10.1590/S0102-09352000000500005>. Accessed:Apr. 12,2018. doi: 10.1590/S0102-09352000000500005.

DAVID, C.M.G. et al. Padrão hematológico de ovelhas da raça Morada Nova antes do parto. Biológico, v.73, n.2, p.246-249, 2011. Available from: <http://www.biologico.agricultura.sp.gov.br/ uploads/docs/bio/v73_2/p246-249.pdf>. Accessed: Apr. 12, 2018.
FONTEQUE, J.H. et al. Leukocyte count and neutrophil oxidative burst in Saanen goats in the pregnancy, parturition and postpartum periods. Pesquisa Veterinária Brasileira, v.33, suppl.1, p.6370, 2013. Available from: <https://doi.org/10.1590/S0100736X2013001300011>. Accessed: Apr. 12, 2018. doi: 10.1590/ S0100-736X2013001300011.

FORTAGNE, M.; SCHÄFER, M. Hematologic parameters of Probstheidaer pigmy goats in relation to pregnancy and lactation. Arch. Exp. Veterinarmed, v.43, n.2, p.223-230, 1989. Available from: <https://pubmed.ncbi.nlm.nih.gov/2774819>. Accessed: Apr. 12, 2018. PMID: 2774819.

ISLAM, S. et al. Hematological reference values for healthy fattailed sheep (Dhumba) in Bangladesh. Journal of Advanced Veterinary and Animal Research, v.5, n.4, p.481-484, 2018. Available from: <https://www.ncbi.nlm.nih.gov/pmc/articles/ PMC6702908/pdf/JAVAR-5-481.pdf $>$. Accessed: Apr. 12, 2020. doi: 10.5455/javar.2018.e302.

JAIN, N.C. 1993. Essentials of veterinary hematology. $1^{\text {a }}$ ed. Philadelphia: Lea \& Febiger. p. 215-293.

JELÍNEK, P. et al. Dynamics of the basal haematological values of ewes in the course of a year. Veterinary Medicine (Praha), v.31 n.6, p.359-370, 1986. Available from: <https://pubmed.ncbi. nlm.nih.gov/3088807> . Accessed: Apr. 12, 2020. PMID: 3088807.

JONES, A.K.; REED, S.A. Benefits of ultrasound scanning during gestation in the small ruminant. Small Ruminant Research, v.149, p.163-171, 2017. Available from: <https://doi.org/10.1016/j. smallrumres.2017.02.008>. Accessed: Apr. 12, 2020. doi: 10.1016/j.smallrumres.2017.02.008.

KANDIEL, M.M.M. et al. Changes in some hematobiochemical and hormonal profile in Barki sheep with various reproductive statuses. Small Ruminant Research, v.136, p.87-95, 2016. Available from: $<$ https://doi.org/10.1016/j.smallrumres.2016.01.011>. Accessed: Apr. 12, 2020. doi: 10.1016/j.smallrumres.2016.01.011.

KANEKO, J.J et al. Clinical biochemistry of domestic animals. $6^{\text {a }}$ ed. New York, Academic Press. p. 930-938, 2008.

LIMA, M.B., et al. Blood reference intervals and the influence of age and gender on hematologic and biochemical parameters of Santa Ines sheep breed in the eastern Amazon. Acta Amazonica, v.45, n.3, p.317-322, 2015. Available from: https://doi. org/10.1590/1809-4392201402115. Accessed: Apr. 12, 2020. doi: $10.1590 / 1809-4392201402115$.

MADUREIRA, K.M. et al. Hematological and biochemical parameters of Dorper ewes. Semina: Ciências Agrárias, v.34, n.2, p.811-816, 2013. Available from: $<$ http://dx.doi.org/10.5433/16790359.2013v34n2p811>. Accessed: Apr. 12, 2020. doi: 10.5433/1679-0359.2013v34n2p811.

MBASSA, G.K.; POULSEN, J.S.D. Influence of pregnancy, lactation and environment of haematological profiles in Danish Landrace dairy goats (capra hircus) of different party. Comparative Biochemistry and Physiology Part B: Comparative Biochemistry, v.100, n.2., p.403-412, 1991. Available from: $<$ https://doi.org/10.1016/0305-0491(91)90394-S>. Accessed: Apr. 12, 2020. doi: 10.1016/0305-0491(91)90394-S.

MBASSA, G.K.; POULSEN, J.S.D. The comparative haematology of cross-bred and indigenous East Agrican goats of 
Tanzania and breeds reared in Denmark. Veterinary Research Communications, v.16, p.221-229, 1992. Available from: $<$ https://doi.org/10.1007/BF01839159>. Accessed: Apr. 12, 2020. doi: $10.1007 / \mathrm{BF} 01839159$.

MCMANUS, C. et al. Heat tolerance in Brazilian sheep: physiological and blood parameters. Tropical Animal Health and Production, v.41, p.95-101, 2009. Available from: $<$ https://doi. org/10.1007/s11250-008-9162-1>. Accessed: Apr. 12, 2020. doi: $10.1007 / \mathrm{s} 11250-008-9162-1$.

MEYER D.J.; HARVEY, J.W. Veterinary laboratory medicine: interpretation $\&$ diagnosis. $2^{\text {a }}$ ed. Philadelphia: Saunders. 351p, 2004.

MOHAMMED, A. et al. Serum Copper and Haematological values of sheep of different physiological stages in the dry and wet seasons of Central Trinidad. Veterinary Medicine Internacional, ID 972074, 2014. Available from: <https:// doi.org/10.1155/2014/972074>. Accessed: Apr. 12, 2020. doi: $10.1155 / 2014 / 972074$

MUSK, G.C. et al. Pregnant sheep in a Farm Environment Did Not Develop Anaemia. Animals, v.7, n.5, p.1-9, 2017. Available from: $<$ https://doi.org/10.3390/ani7050034>. Accessed: Apr. 12, 2020. doi: 10.3390/ani7050034.

NRC. Nutrient Requirements of small ruminants: sheep, goats, cervids and new world camelids. Natl Acad. Press, Washington, DC. 384 p, 2007.

OIKONOMIDIS, I.L. et al. Combined and breed-specific RIs for hematologic, biochemical, and hormonal analytes in Chios and Florina adult rams. Veterinary Clinical Pathology, v.47, n. 1, p.5668, 2018. Available from: <https://doi.org/10.1111/vcp.12558>. Accessed: Apr. 12, 2020 doi: 10.1111/vcp. 12558.

OLIVEIRA, W.D.O. et al. Changes in hematological biomarkers of Nellore cows at different reproductive stages. Acta Scientiarum. Animal Sciences, v.41, e45725, 2019. Available from: <http:// dx.doi.org/10.4025/actascianimsci.v41i1.45725>. Accessed: Apr. 12, 2020 doi: 10.4025/actascianimsci.v41i1.45725.

PEREIRA, F.B. et al. Hematological profile of Santa Inês ewes supplemented on pasture at the last third of pregnancy and postpartum. Ciência Animal Brasileira, v.16, n.3, p.350357, 2015. Available from: <https://doi.org/10.1590/10896891v16i327573>. Accessed: Apr. 12, 2020. doi: 10.1590/1089$6891 v 16 \mathrm{i} 327573$.

RUSSEL, A. Body condition scoring of sheep. In: E. Boden (Ed.) Sheep and goat practice. Bailliere Tindall, Philadelphia. p.3-4, 1991.

SALVIANO, M.B. et al. Valores hematológicos de ovelhas Santa Inês adultas não prenhes. Revista Científica Eletrônica de Medicina Veterinária, v.11, n.20, p.2-12, 2013. Available from: $<$ https://docplayer.com.br/2797748-Valores-hematologicos-deovelhas-santa-ines-adultas-nao-prenhes-hematologic-sheep-ofsanta-ines-adults-not-pregnant.html>. Accessed: Apr. 12, 2020.
SANTAROSA, B.P. et al. Comparison of biochemical parameters between single and twin pregnancies of Dorper breed ewes during gestation, lambing and postpartum. Arquivo Brasileiro de Medicina Veterinária e Zootecnia, v.71, n.4, p. 1307-1315, 2019. Available from: <http://dx.doi. org/10.1590/1678-4162-10699>. Accessed: Nov. 20, 2019. doi: 10.1590/1678-4162-10699.

SANTAROSA, B.P. Avaliação clínica, hemogasométrica do perfil metabólico e do estresse oxidativo de ovelhas prenhes da raça Dorper: comparação entre gestações única e gemelar. 2018. 100f. Tese (Doutorado) - Curso de Pósgraduação em Medicina Veterinária, Universidade Estadual Paulista (UNESP), Botucatu.

SHARMA, A. et al. Haemato-biochemical and endocrine profiling of north western Himalayan Gaddi sheep during various physiological/reproductive phases. Open Veterinary Journal, v.5, n.2, p.103-107, 2015. Available from: <https:/www.ncbi.nlm. nih.gov/pmc/articles/PMC4663804/pdf/OpenVetJ-5-103.pdf>. Accessed: Apr. 12, 2020. PMID: 26623374.

STARLING, R.Z.C. et al. Losses caused by gastrointestinal nematode infections in Dorper lambs under two nutritional status. Brazilian Journal of Veterinary Parasitology, v.28, n.4, p.652-660, 2019. Available from: <https://doi.org/10.1590/s198429612019084>. Accessed: Apr. 12, 2020. doi: 10.1590/s1984 29612019084.

TAVERNE, M.A.M. et al. Accuracy of pregnancy diagnosis and prediction of foetal numbers in sheep with linear-array real-time ultrasound scanning. Veterinary Quarterly, v.7, n.4, p.256-263, 1985. Available from: <https://doi.org/10.10 80/01652176.1985.9693997>. Accessed: Apr. 12, 2020. doi: 10.1080/01652176.1985.9693997.

THRALL, M.A. et al. Hematologia e bioquímica clínica veterinária. São Paulo, Roca. p.140-304, 2015.

VIANA, R.B. et al. Influence of pregnancy and puerperium in the leucogram of Saanen goats (Capra hircus) breed in the state of São Paulo. Brazilian Journal Of Veterinary Research and Animal Science, v.39, n.4, p.196-201, 2002. Available from: <https://doi.org/10.1590/S141395962002000400006>. Accessed: Apr. 12, 2020. doi: 10.1590/ S1413-95962002000400006.

VIANA, R.B. et al. Influence of pregnancy and puerperium in the eritrogram of Saanen goats (Capra hircus) breed in the state of São Paulo. Brazilian Journal Of Veterinary Research and Animal Science, v.40, n.3, p.178-184, 2003. Available from: $<$ https://doi. org/10.1590/S1413-95962003000300003>. Accessed: Apr. 12, 2020. doi: 10.1590/S1413-95962003000300003.

YOKUS, B. et al. Effects of seasonal and physiological variations on the serum major and trace element levels in Sheep. Biological Trace Element Research, v.101, n.3, p.241-255, 2004. Available from: $\quad<$ https://link.springer.com/article/10.1385\%2FBTER $\% 3$ A101\%3A3\%3A241>. Accessed: Apr. 12, 2020. doi: 10.1385/ BTER:101:3:241. 